\title{
IDENTIFIKASI KANDUNGAN KROMIUM (Cr) PADA LIMBAH CAIR DAN KERUPUK RAMBAK SEBAGAI UPAYA PENCEGAHAN TERHADAPDAMPAK KESEHATAN
}

\author{
Fitria Nur Azizah, Prehatin Trirahayu Ningrum, Ellyke \\ Universitas Jember, Jalan Kalimantan 37 Kampus Tegal Boto Jember 68121 \\ Email: fitriaazizah95@gmail.com
}

\section{Identification of Content Chromium (Cr) on Liquid Waste and Rambak Cracker as Prevention Efforts Against Health Impact}

\begin{abstract}
The process of making crackers rambak will produce liquid waste that indicates chromium. This study aims to analyze the chromium content of liquid waste and crackers in rambak cracker industry UD.X in Kaliwates District, Jember Regency. This research uses descriptive research method. The sample of this study using grab sampling for liquid waste removal that is as much as $1.5 \mathrm{~L}$ and purposive sampling for taking raw skin and crackers rambak as much as 10 grams. The results of this study indicate that the stage of making rambak crackers UD.X namely boiling stage, cutting, spinning, drying, frying I and frying II. Laboratory test results, liquid waste samples containing chromium of 2.17 $\mathrm{mg} / \mathrm{l}$. Raw skin sample was $0.0315 \mathrm{mg} / \mathrm{kg}$ and cracker rambak was $0.0426 \mathrm{mg} / \mathrm{kg}$.
\end{abstract}

Keywords: liquid waste, raw skin, rambak cracker and chromium

\begin{abstract}
Abstrak: Proses pembuatan kerupuk rambak akan menghasilkan limbah cair yang mengindikasikan mengandung kromium. Penelitian ini bertujuan untuk menganalisis kandungan kromium pada limbah cair dan kerupuk rambak di industri kerupuk rambak UD.X di Kecamatan Kaliwates Kabupaten Jember. Penelitian ini menggunakan metode peneltian deskriptif. Sampel penelitian ini menggunakan grab sampling untuk pengambilan limbah cair yakni sebanyak 1,5 L dan purposive sampling untuk pengambilan kulit mentah dan kerupuk rambak yakni sebanyak 10 gram. Hasil penelitian ini menunjukkan bahwa tahap pembuatan kerupuk rambak UD.X yaitu tahap perebusan, pengguntingan, pembumbuan, penjemuran, penggorengan I dan penggorengan II. Hasil pemeriksaan uji laboratorium, sampel limbah cair mengandung kromium sebesar 2,17 mg/l. Sampel kulit mentah sebesar 0,0315 mg/ $\mathrm{kg}$ dan kerupuk rambak sebesar 0,0426 $\mathrm{mg} / \mathrm{kg}$.
\end{abstract}

Kata kunci: limbah cair, kulit mentah, kerupuk rambak dan kromium

\section{PENDAHULUAN}

Pangan yang dikonsumsi masyarakat harus berkualitas dengan memenuhi beberapa kriteria, diantaranya aman, bergizi, beragam, dan tersedia cukup merupakan prasyarat utama yang harus dipenuhi dalam upaya terselenggaranya sistem pangan yang memberikan perlindungan kesehatan serta berperan dalam meningkatkan kemakmuran dan kesejahteraan manusia (UU No. 52 Tahun 2004). Keamanan pangan adalah kondisi dan upaya yang diperlukan untuk mencegah pangan dari kemungkinan cemaran biologis, kimia, dan benda lain yang dapat mengganggu, merugikan, dan membahayakan kesehatan manusia sehingga aman untuk dikonsumsi(UU No. 18 Tahun 2012).

Berdasarkan data peternakan dan kesehatan hewan tahun 2015 menyebutkan bahwa Provinsi Jawa Timur melakukan impor kulit sebesar 1.655.319 lembar. Pemanfaatan kulit sapi mentah di Indonesia dapat digunakan sebagai bahan kerajinan kulit dan bahan pangan. Salah satu olahan makanan yang berasal dari kulit sapi yaitu kerupuk kulit atau biasa disebut dengan kerupuk rambak. Kerupuk rambak kulit adalah produk makanan ringan yang dibuat dari kulit sapi atau kerbau melalui tahap proses pembuangan bulu, pembersihan kulit, perebusan, pengeringan dan 
perendaman dengan bumbu untuk kerupuk rambak mentah dan dilanjutkan dengan penggorengan untuk kerupuk rambak siap konsumsi [SNI 01-4308-1996].

Kulit lokal yang semakin sulit didapatkan karena persaingan permintaan untuk industri penyamakan kulit, menyebabkan beberapa industri kerupuk rambak kulit menggunakan kulit impor sebagai bahan baku kerupuk rambak. Pada kerupuk kulit yang berbahan baku dari sisa bahan yang berasal dari pabrik penyamakan kulit banyak mengandung zat kimia berbahaya dan zat pewarna seperti kromium. Kadar baku mutu yang ditetapkan oleh Dirjen POM No.03725/ B/SK/VII/89 Tentang Batas Maksimal Cemaran Logam dalam Makanan yakni sebesar 2,5 mg/ $\mathrm{kg}$. Selain itu, pada proses pembuatan kerupuk rambak juga menghasilkan limbah cair yang berasal dari proses perebusan kulit yang memungkinkan mengandung kromium. Limbah cair dari suatu industri yang dilakukan pengolahan terlebih dahulu maupun tidak, pada akhirnya akan dibuang ke lingkungan yang paling banyak ke sungai. Berdasarkan Peraturan Gubernur Jawa Timur Nomor 52 tahun 2014 tentang Baku Mutu Air Limbah Bagi Industri dan/atau Kegiatan Usaha Lainnya menyebutkan batas maksimal air limbah untuk baku mutu air limbah golongan I sebesar 0,1 mg/l.

Kegiatan industri di Kabupaten Jember salah satunya banyak dijumpai yaitu industri rumah tangga yang menghasilkan produksi kerupuk. Kerupuk rambak merupakan salah satu produk unggulan di Kabupaten Jember. Salah satu industri kerupuk rambak di Kabupaten Jember yang sudah terdaftar yaitu UD.X yang terletak di Kecamatan Kaliwates. Berdasarkan studi pendahuluan pada industri kerupuk rambak UD.X di Kecamatan Kaliwates bahwa bahan baku kulit yang digunakan berasal dari pabrik penyamakan kulit yang berasal dari Malang.

Tujuan penelitian ini adalah untuk menganalisis kandungan kromium $(\mathrm{Cr})$ pada limbah cair dan kerupuk rambak di Industri Kerupuk Rambak UD.X di Kecamatan Kaliwates Kabupaten Jember.

\section{METODE PENELITIAN}

Jenis penelitian yang digunakan adalah penelitian deskriptif. Penelitian ini dilakukan di Industri Kerupuk Rambak UD.X Kecamatan Kaliwates Kabupaten Jember. Uji laboratorium dilakukan di Laboratorium Kesehatan Daerah Jember dan Laboratorium Polteknik Negeri Jember. Penelitian ini dilakukan bulan Agustus 2017. Total populasi seluruh limbah cair yang dihasilkan yaitu $\pm 120 \mathrm{~L} /$ hari, seluruh bahan baku kulit mentah yang diolah yaitu $\pm 150 \mathrm{~kg}$ /hari, dan seluruh kerupuk rambak yang diolah yaitu \pm 100 $\mathrm{kg} /$ hari. Sampel yang digunakan dalam penelitian ini adalah grab sampling dan purposive sampling. Variabel penelitian ini meliputi proses pembuatan kerupuk rambak, kandungan kromium (Cr) pada limbah cair, dan kandungan kromium (Cr) pada kulit mentah dan kerupuk rambak.

Pengambilan sampel limbah cair dilakukan selama 3 hari. Pengambilan sampel pada satu tempat yaitu bak perebusan. Pengujian sampel limbah cair dilakukan oleh Laboratorium Kesehatan Daerah. Hasil pengujian disajikan dengan Tabel.

Pengambilan sampel kulit sapi dilakukan dengan mengambil 2 macam sampel yaitu kulit sapi mentah dan kerupuk rambak matang yang siap dikonsumsi. Banyaknya sampel terdiri dari 3 sampel kulit mentah dan 3 sampel kerupuk rambak. Pengujian dilakukan oleh Laboratorium Politeknik Negeri Jember.

Sumber data penelitian adalah data primer dan data sekunder. Data primer yaitu dari hasil wawancara dan observasi, serta uji laboratorium. Sedangkan data sekunder diperoleh dari Dinas Perindustrian dan Perdagangan Kabupaten Jember. Penyajian data dalam penelitian ini 
berupa narasi dan tabel. Analisis data yang dilakukan peneliti dalam hal ini adalah menggunakan deskriptif bertujuan untuk menggambarkan proses pembuatan kerupuk rambak, hasil uji laboratorium tentang kadar kromium pada limbah cair, dan kadar kromium kerupuk rambak di kulit mentah dan kerupuk rambak.

\section{HASIL PENELITIAN}

Berdasarkan Tabel 1 menunjukkan hasil pengujian kandungan kromium pada hari kedua menunjukkan paling banyak sebesar $2,19 \mathrm{mg} / \mathrm{l}$. Hasil pengujian rata-rata selama 3 hari menunjukkan kandungan kromium 2,17 mg/l. Berdasarkan hasil wawancara dengan pekerja selama 3 hariberturut-turut mengolah banyaknya kulit untuk direbus sebanyak $120 \mathrm{~kg}, 150 \mathrm{~kg}$, dan $100 \mathrm{~kg}$.

Tabel 1. Kadar Kromium pada Limbah Cair

\begin{tabular}{lc}
\hline Hari ke- & Hasil (mg/l) \\
\hline Hari I & 2,19 \\
Hari II & 2,60 \\
Hari III & 1,73 \\
\hline Rerata & 2,17 \\
\hline
\end{tabular}

Tabel 2. Kadar Kromium pada Kulit Sapi Mentah

\begin{tabular}{lc}
\hline Sampel Kulit & Hasil (mg/kg) \\
\hline Sampel Kulit 1 & 0,0315 \\
Sampel Kulit 2 & 0,0315 \\
Sampel Kulit 3 & 0,0314 \\
\hline Rata-rata & 0,0315 \\
\hline
\end{tabular}

Tabel 3. Kadar Kromium pada Kerupuk Rambak Matang

\begin{tabular}{lc}
\hline Sampel Kerupuk & Hasil (mg/kg) \\
\hline Sampel Kerupuk 1 & 0,0426 \\
Sampel Kerupuk 2 & 0,0425 \\
Sampel Kerupuk 3 & 0,0427 \\
\hline Rata-rata & 0,0426 \\
\hline
\end{tabular}

Berdasarkan Tabel 2 menunjukkan hasil pengujian kandungan kromium pada sampel kulit sapi mentah menunjukkan angka yang tidak jauh berbeda. Hasil pengujian kandungan kromium pada sampel kulit sapi didaptkan hasil rata-rata $0,0315 \mathrm{mg} / \mathrm{kg}$.

Berdasarkan Tabel 3 menunjukkan hasil pengujian kandungan kromium pada sampel kerupuk rambak didapatkan hasil rata-rata $0,0426 \mathrm{mg} / \mathrm{kg}$.

\section{PEMBAHASAN}

Menurut SNI 01-4308-1996, kerupuk rambak kulit adalah produk makanan ringan yang dibuat dari kulit sapi atau kerbau melalui tahap proses pembuangan bulu, pembersihan kulit, perebusan, pengeringan dan perendaman dengan bumbu untuk kerupuk rambak mentah dan dilanjutkan dengan penggorengan untuk kerupuk rambak siap konsumsi. Berdasarkan hasil penelitian yang dilakukan di industri kerupuk rambak UD.X yaitu memiliki beberapa tahap. Tahap pertama yaitu proses perebusan dimana bahan baku yang diolah sudah dalam keadaan bersih tanpa bulu sehingga mempermudah dalam proses pembuatan kerupuk. Selain itu, untuk mempersingkat waktu produksi yang tanpa melakukan perendaman kapur dan pengerokan bulu pada bahan baku yaitu kulit sapi mentah. Tahap kedua yaitu proses pengguntingan yang terdapat 2 tahap. Pada tahap pertama kulit masih dalam lembaran besar lalu dipotong menjadi ukuran memanjang kemudian pada tahap kedua akan dipotong kembali menjadi lebih kecil. Tahap ketiga yaitu proses pemberian bumbu meliputi bawang putih, garam, MSG dan air secupuknya. Tahap keempat yaitu proses penjemuran yang membutuhkan waktu minimal satu hari untuk menghasilkan kerupuk menjadi kering. Tahap kelima yaitu proses penggorengan I dan penggorengan II. Proses penggorengan I menghasilkan kerupuk setengah matang dalam 
keadaan belum mengembang. Selanjutnya, proses penggorengan II lanjutkan dari hasil kerupuk setengah matang yang kemudian digoreng kembali dengan minyak panas sehingga menghasilkan kerupuk yang mengembang dengan tekstur renyah dan gurih. Kerupuk rambak yang sudah matang akan dikemas dalam kemasan plastik yang siap di distribusikan dan bisa langsung dikonsumsi oleh masyarakat.

Berdasarkan penelitian Amertaningtyas (2011) bahwa proses pembuatan kerupuk rambak pertama kali dilakukan pemilihan kulit sebagai bahan baku kulit (harus dari kulit yang sehat, bukan dari ternak yang sakit, kulit bersih dan tidak busuk), pencucian kulit untuk menghilangkan kotoran, perendaman diperlukan jika kulit dalam keadaan kering, pengapuran kulit, pembuangan kapur, pembuangan bulu, perebusan kulit, pengguntingan, perendaman dalam bumbu, pengeringan, kemudian penggorengan. Pada tahapan proses pembuatan kerupuk rambak UD.X yang membedakan tidak terdapat proses perendaman, pengapuran, penghilangan bulu dan pembuangan kapur. Pada tahap ini dilakukan apabila kulit yang akan diolah menjadi kerupuk rambak masih dalam keadaan utuh terdapat bulu-bulu. Sedangkan bahan baku yang digunakan oleh industri kerupuk rambak UD.X berasal dari limbah penyamakan kulit yang sudah dalam keadaan bersih tanpa bulu.

Bahan baku kerupuk rambak yang digunakan oleh UD.X yang berasal dari pabrik penyamakan kulit. Limbah dari pabrik penyamakan kulit mengandung bahan-bahan kimia yang digunakan hanya berkisar $70 \%$ saja yang terikat pada kulit sedangkan sisanya terdapat dalam bentuk limbah cair maupun limbah padat. Menurut Hutagalung (1984), mengatakan bahwa peningkatan suhu akan menyebabkan toksisitas dari suatu logam berat meningkat. Hal ini mengindikasikan kerupuk rambak yang mengandung kromium $(\mathrm{Cr})$ akan mengalami peningkatan selama proses pembuatan yang mengalami proses peningkatan suhu yaitu dari proses perebusan.

Berdasarkan hasil pengujian air limbah yang dihasilkan oleh UD.X yaitu rata-rata $2,17 \mathrm{mg} / 1$ mengandung kromium. Hasil menunjukkan bahwa kandungan kromium tidak memenuhi persyaratan Baku Mutu Lingkungan (BML) yang telah ditetapkan oleh Peraturan Gubernur Jawa Timur Nomor 52 Tahun 2014 bahwa batas maksimal air limbah untuk baku mutu air limbah golongan I sebesar 0,1 mg/l. Keberadaan krom di perairan dapat menyebabkan penurunan kualitas air serta membahayakan lingkungan dan organisme akuatik (Susanti dan Henny, 2008). Berdasarkan hasil penelitian Homa et al., (2016) terkait kontaminasi kromium di sekitar kawasan industri bahwa didapatkan terdapat kandungan kromium yang mencemari tanah sehingga hal ini menyebabkan tanah tersebut tidak sesuai untuk keperluan pertanian.

Berdasarkan hasil penelitian di industri UD.X bahwa hasil pengujian laboratorium kandungan kromium rerata pada kulit sapi mentah sebelum diolah menjadi kerupuk rambak sebesar 0,0315 $\mathrm{mg} / \mathrm{kg}$. Sedangkan, hasil pengujian laboratorium kandungan kromium rerata pada kerupuk rambak matang sebesar $0,0426 \mathrm{mg} / \mathrm{kg}$. Nilai ini masih belum melebihi Kadar baku mutu yang sudah ditetapkan oleh Dirjen POM No. 03725/ B/SK/VII/89 Tentang Batas Maksimal Cemaran Logam Dalam Makanan yakni sebesar 2,5 mg/ $\mathrm{kg}$.

Perbedaan kadar logam berat kromium baik sebelum dan sesudah proses pengolahan dapat dipengaruhi oleh beberapa faktor, memungkinkan diantaranya adalah waktu perebusan kulit dan proses pengolahan. Waktu perebusan kulit sapi mentah yang berkisar antara 30-45 menit yang didasarkan apabila kulit tebal akan dilakukan perebusan yang agak lama untuk memperoleh kulit dengan tekstur lembek dan berubah warna. Berdasarkan penelitian Sari et al., (2014), terkait logam berat pada makanan menunjukkan bahwa 
hasil penelitian terkait pengaruh lama perebusan terhadap kadar logam berat pada kerang darah menunjukkan lama perebusan mempengaruhi penurunan kadar logam. Menurut Astawan (1989), dalam proses pembuatan kerupuk rambak pada tahap perebusan kulit sapi mentah dilakukan pada suhu $90^{\circ} \mathrm{C}$ dan dilakukan selama 2 jam selanjutnya diangin-anginkan. Pengolahan bahan makanan yang baik dapat menurunkan kadar logam berat pada bahan pangan sebelum dikonsumsi. Pengolahan bahan pangan juga akan berdampak pada kadar gizi dari bahan pangan tersebut. Menurut penelitian Suandi et al., (2017), terkait bahwa mutu atau kualitas minyak goreng dapat mempengaruhi gizi pangan hasil gorengan dimana minyak sisa gorengan dapat ditentukan berdasarkan nilai bilangan peroksida akibat adanya proses oksidasi. Menurut penelitian Ayu dkk., (2016) bahwa penggunaan minyak goreng yang digunakan secara berulang-ulang dengan pemanasan tinggi dapat menyebabkan penurunan kualitas minyak goreng, sehingga dapat mempengaruhi bahan pangan yang diolah.

Logam kromium $(\mathrm{Cr})$ adalah salah satu jenis polutan logam berat yang bersifat toksik dalam tubuh (Widowati et al., 2008). Apabila logam berat ini terus menerus terakumulasi dalam tubuh manusia maka akan mengakibatkan gangguan kesehatan. Perubahan patologis yang parah dan seringkali mematikan dikaitkan dengan konsumsi senyawa Cr (VI) yang berlebihan. Cr (VI) memberikan efek toksik pada sistem biologis (Bielicka et al., 2005). Mencerna makanan yang mengandung kadar $\mathrm{Cr}$ (VI) tinggi bisa menyebabkan gangguan pencernaan, berupa sakit lambung, muntah dan pendarahan, luka pada lambung, konvulsi, kerusakan ginjal, dan hepar, bahkan dapat menyebabkan kematian.

\section{PENUTUP}

Hasil pemeriksaan kandungan kromium pada air limbah yang dihasilkan oleh industri kerupuk rambak UD.X didapatkan hasil rata- rata 2,17 mg/l. Kandungan kromium tersebut telah melebihi baku mutu limbah yang ditetapkan pada Peraturan Gubernur Jawa Timur Nomor 52 tahun 2014 tentang Baku Mutu Air Limbah Bagi Industri dan/atau Kegiatan Usaha Lainnya menyebutkan batas maksimal air limbah untuk baku mutu air limbah golongan I sebesar $0,1 \mathrm{mg}$ / 1 .

Hasil kandungan rerata kromium pada kulit sapi mentah sebesar 0,0315 mg/kg. Kandungan rerata kromium pada kerupuk rambak matang sebesar $0,0426 \mathrm{mg} / \mathrm{kg}$ yang dihasilkan oleh UD.X. Nilai ini masih belum melebihi Kadar baku mutu yang sudah ditetapkan oleh Dirjen POM No. 03725/B/SK/VII/89 Tentang Batas Maksimal Cemaran Logam Dalam Makanan yakni sebesar 2,5 mg/kg.

Saran yang dapat diberikan bagi Industri Kerupuk Rambak yaitu memanfaatkan buah jeruk nipis untuk dijadikan alternatif perendaman kulit sapiuntuk menurunkan kandungan kromium karena mengandung senyawa asam organik yaitu asam sitrat. Saran bagi Dinas Lingkungan Hidup yaitu perlunya pengawasan terhadap limbah cair yang dihasilkan industri kerupuk rambak serta monitoring pada badan air secara berkala setiap 3 bulan sekali berkaitan dengan parameter logam berat. Saran untuk peneliti selanjutnya perlu dilakukan pemeriksaan kandungan kromium pada setiap hasil perebusan kulit untuk mengetahui lebih jelas dimana tingginya kandungan kromium berada dan pemeriksaan lebih lanjut terkait kandungan BOD, COD, TSS, $\mathrm{Ph}$, minyak dan lemak, $\mathrm{NH}_{3}$, dan Sulfida (S).

\section{DAFTAR PUSTAKA}

Amertaningtyas, D. (2011). Pengolahan Kerupuk Rambak Kulit di Indonesia. Jurnal IlmuIlmu Peternakan. 21 (3):18-29.

Astawan, M. (1989). Teknologi Pengolahan Pangan Tepat Guna. Jakarta: Akademika Pressindo. 
Ayu, A., Rahmawati, F., \& Zukhri, S. (2016). Pengaruh Penggunaan Berulang Minyak Goreng terhadap Peningkatan Kadar Asam lemak Bebas dengan Metode Alkalimetri. CERATA Jurnal Ilmu Farmasi (Journal of Pharmacy Science), 6(1).

Bielicka, A., I. Bojanowska, dan A. Wisniewski. (2005). Two Faces ofChromium-Pollutant and Bioelement. Polish Journal of Environmental Studies 14 (1): 5-10.

Homa, D., E. Haile, dan A. P. Washe. (2016). Determination of Spatial Chromium Contamination of the Environmental around Industrial Zones. International Journal of Analytical Chemistry 2016:7.

Hutagalung, H.P. (1984). Logam Berat dalam Lingkungan Laut. Oseana. Vol. IX, No. 4. Puslitbang Oseanologi-LIPI. Jakarta. Hal $11-20$

Keputusan Direktur Jenderal Pengawasan Obat dan Makanan Nomor 0375/B/SK/VII/89 tentang Batas Maksimal Cemaran Logam dalam Makanan

Peraturan Gubernur Jawa Timur Nomor 52 Tahun 2014 tentang Baku Mutu Air Limbah Bagi Industri dan/atau Kegiatan Usaha Lainnya

Sari, K. A., P. H. Riyadi dan A. D. Angga. (2014). Pengaruh Lama Perebusan dan Konsentrasi Larutan Jeruk Nipis (Citrus aurantifolia) Terhadap Kadar Timbal (Pb) dan Kadmium (Cd) pada Kerang Darah (Anadara granosa). Jurnal Pengolahan dan Bioteknologi Hasil Perikanan, 3(2): 110. Universitas Diponegoro.

SNI 01-4308-1996. Kerupuk Kulit. Badan Standarisasi Nasional

Sundari, D., Almasyuri, dan A. Lamid. (2015). Pengaruh Proses Pemasakan Terhadap Komposisi Zat GiziBahan Pangan Sumber Protein. Media Litbangkes, 25(4):235-242

Susanti, E., Henny. (2008). Pedoman Pengolahan Limbah Cair yang Mengandung Kromium Dengan Sistem Lahan Basah Buatan Dan Reaktor Kolom. Pusat Penelitian Limnologi. LIPI. Cibinong. 49 hal. Suandi, D. A. P., N. M. Suaniti dan A. A. B. Putra. (2017). Analisis Bilangan Peroksida Minyak Sawit hasil Gorengan Tempe pada Berbagai Waktu Pemanasan dengan Titrasi Iodometri. Jurnal Kimia, 11 (1):69-74. Universitas Udayana.

Undang-undang Nomor 52 Tahun 2014 tentang keamanan, Mutu, dan Gizi Pangan

Undang-Undang Nomor 18 Tahun 2012 tentang Pangan

Widowati, W. (2008). Efek Toksik Logam. Yogyakarta: Penerbit Andi 